\title{
Clinical Evaluation of a Self-Adhering Flowable Resin Composite in Minimally Invasive Class I Cavities: 5-year Results of a Double Blind Randomized, Controlled Clinical Trial
}

\section{Klinička procjena samoadhezivnih tekućih kompozita u liječenju minimalno invazivnih kaviteta I. razreda: petogodišnji rezultati dvostruko slijepoga randomiziranog kontroliranog kliničkog istraživanja}

\begin{abstract}
Department of Restorative Dentistry, School of Dentistry, Hacettepe University, Sihhiye, 06100, Ankara, TURKEY Zavod za restaurativnu stomatologiju Stomatološkog fakulteta Sveučilišta Hacettepe, Sihhiye, 06100, Ankara, Turska
\end{abstract}

Abstract

Objective: The aim of this study was to evaluate the long-term clinical performance of a self-adhering flowable resin composite compared to a conventional flowable resin composite used with an etch\&rinse adhesive system in minimally invasive Class I cavities. Materials and Methods: Twentyfive patients received at least one pair of Class I restorations $(n=65)$. After Class I cavities had been prepared, they were randomly restored either with a self-adhering flowable resin composite (VertiseFlow/Kerr-VR) [Group-1 $(n=33)$ ], or with a flowable resin composite (Luxaflow/DMG-LX) in combination with an etch\&rinse adhesive (Teco/DMG) [Group-2 $(n=32)]$ according to the manufacturers' instructions. The restorations were evaluated at baseline and yearly during 5 years according to the FDI criteria by two evaluators. A statistical analysis was carried out using the Pearson Chi-Square test and the Cochran Q-test followed by the Mc Nemar's test $(p=0.05)$. Results: After 5 years a total of 47 restorations were evaluated with a recall rate of $68 \%$. At 4-year, 3 (11.5\%) VR and 2 LX (7.6\%) restorations exhibited a cumulative retention loss. Seventeen (73.9\%) VR and 14 LX (58.3\%) restorations exhibited clinically acceptable (2) scores for marginal adaptation. At 5-year evaluations VR and LX showed similar results regarding all evaluated criteria $(p>0.05)$. The cumulative retention loss rates of $V R$ and $L X$ were $15.3 \%$ and $7.6 \%$, respectively. None of the restorations demonstrated a recurrence of caries and post operative sensitivity. Both materials showed significant changes at 4 and 5 years regarding marginal staining when compared to baseline $(p<0.001)$. Furthermore, significant changes were observed for VR and LX at 1, 2, 3, 4 and 5 years for marginal adaptation according to baseline $(p<0.001)$. Conclusion: The use of both materials for the restoration of Class-I cavities demonstrated clinically acceptable performance at the end of 5 -year. The self-adhering flowable composite exhibited a clinical performance similar to the conventional flowable applied with an etch\&rinse adhesive.
Received: January 12, 2020

Accepted: March 1, 2020

Address for correspondence Fatma Dilsad Oz, DDS, PhD Hacettepe University, School of Dentistry

Department of Restorative Dentistry, Sihhiye, 06100, Ankara, TURKEY Phone: +903123052270 Fax: +903123113438 dilsadoz@yahoo.com

Key words

Dental Restoration, Permanent; Composite Resins; Adhesiveness; Dental Marginal Adaptation

\section{Introduction}

The occlusal morphology of pit and fissures is the main reason for development of dental caries at this region $(1,2$, $3)$. Various restorative materials can be used clinically for the restoration of occlusal cavities clinically, e.g. glass ionomer cements, compomers and flowable resin composites $(4,5)$.

Flowable composite resins were first introduced in 1972 by Ibsen for the restoration of non-carious cervical lesions, and later these resin composites have found numerous application areas in dentistry such as Class II restorations and Class V cavities which are in need of stress relieving $(6,7)$. The applicability of flowable resin composites for Class I cav-
Uvod

Okluzalna morfologija s fisurama i jamicama glavni je razlog za razvoj zubnog karijesa u tom području $(1,2,3)$. Za restauraciju okluzalnih kaviteta klinički se mogu upotrijebiti različiti restaurativni materijali, npr. staklenoionomerni cementi, kompomeri i tekući kompoziti $(4,5)$.

Tekuće kompozite prvi je upotrijebio Ibsen 1972. za restauraciju nekarijesnih cervikalnih lezija, a poslije su ti materijali prošireni na mnoge druge indikacije u dentalnoj medicini, kao što su restauracije II. razreda i kaviteti V. razreda koji zahtijevaju smanjenje naprezanja $(6,7)$. Primjena tekućih kompozita za kavitete I. razreda povećala se s razvojem tih 
ities has expanded with the development of these materials. Low viscosity, low modulus of elasticity, and ease of handling are some of the desirable properties of flowable resin composites (8). The filler loading of flowable resin composites (weight: 60-70\%; volume: 46-65\%) is reduced compared to conventional hybrid composites (weight: 70-80\%; volume: $60-75 \%$ ) that are considered conventional resin composites $(9,10)$. This altered filler loading modifies the viscosity of flowable resin composites. In general, they are packed in small syringes which allow easy dispensing with very small gauge needles, thus allowing clinicians to use flowable resin composites in small preparations that would be difficult to fill otherwise (8). Flowable resin composites can be preferred on stress bearing occlusal surfaces. In addition, they offer different shade options to provide better esthetics (11). Therefore, flowable resin composites have traditionally been used for small Class I, II cavities and Class V lesions for years (8).

The application time of adhesive systems is variable. It is within the range of 36-115 seconds according to the manufacturer's instructions. Besides, the number of clinical application steps is greater in etch- and- rinse systems compared to self-etch systems. In an attempt to reduce procedure steps, a self-adhering flowable resin composite (Vertise Flow, Kerr, Orange, USA) was introduced in the market. The advantage of the Vertise Flow over fissure sealants is its availability in nine different shades. Also, the Vertise Flow has shorter application time, and can be used in small Class I restorations and as base/liner material for Class I and II restorations. Although the results of few clinical studies on the Vertise Flow were published $(12,13)$, long-term clinical results have not been published yet. Therefore, the aim of this study was to evaluate the 5-year clinical performance of self-adhering flowable resin composite compared to a conventional flowable resin composite used with an etch and rinse adhesive system. The null hypothesis tested was that there would be no difference between the two flowable resin composite placed in minimally invasive Class I cavities.

\section{Material and methods}

The experiment design followed the Consolidated Standards of Reporting Trials (CONSORT) statement (14). The ethical approval for the study was obtained by the Institutional Clinical Investigations Ethics Committee (Ethic No: HEK 11/40-12). All participants voluntarily participated in the study and were required to sign a written informed consent form.

\section{Protocol Registration}

This clinical trial was registered at ClinicalTrials.gov (NCT03556553).

\section{Trial Design, Settings and Location of Data Collection}

This was a double blind, randomized, and controlled clinical trial. The study was carried out in the clinic of Hacettepe University, School of Dentistry, Department of Restorative Dentistry. materijala. Mala viskoznost, nizak modul elastičnosti i jednostavnost rukovanja neka su od njihovih poželjnih svojstava (8). Udio punila u tekućim kompozitima (maseni: 60 - 70 $\%$; volumni: 46 - $65 \%$ ) manji je negoli u klasičnim hibridnim kompozitima (maseni: 70 - 80\%; volumni: 60 - 75 $\%$ ) koji se smatraju konvencionalnima $(9,10)$. Taj izmijenjeni udio modificira viskoznost tekućih kompozita. Općenito, pakirani su u štrcaljkama koje omogućuju jednostavnu aplikaciju s pomoću malih nastavaka i mogu se upotrebljavati u kavitetima koje bi inače bilo teško opskrbiti (8). Tekući kompoziti mogu se primijeniti na okluzalnim plohama koje su izložene većem naprezanju. $\mathrm{Uz}$ to, proizvode se u različitim bojama radi bolje estetike (11). Stoga se tekući kompoziti godinama tradicionalno koriste za male kavitete I. i II. razreda te za restauracije $V$. razreda (8).

Vrijeme aplikacije adhezivnih sustava razlikuje se i kreće se u rasponu od 36 do 115 sekunda, u skladu s uputama proizvođača. Uz to, broj koraka veći je za jetkajuće-ispiruće sustave u usporedbi sa samojetkajućima. U pokušaju da se smanji broj koraka i skrati procedura, na tržištu je pojavio samoadhezivni tekući kompozit (Vertise Flow, Kerr, Orange, SAD). Prednost Vertise Flowa u odnosu prema smolama za pečacenje fisura jest njegova dostupnost u devet različitih boja. Također ima kraće vrijeme aplikacije i može se upotrijebiti u malim restauracijama I. razreda i kao podloga za restauracije I. i II. razreda. Iako su u nekoliko kliničkih istraživanja autori izvijestili o rezultatima postignutima za Vertise Flow $(12,13)$, dugoročni klinički rezultati još ne postoje. Zato je cilj ovog istraživanja bio procijeniti petogodišnju kliničku učinkovitost toga samoadhezivnog tekućeg kompozita u usporedbi s konvencionalnim tekućim kompozitom koji se primjenjuje u kombinaciji s jetkajuće-ispirućim adhezivnim sustavom. Nulta hipoteza glasila je da nema razlike između dvaju tekućih kompozitnih materijala upotrijebljenih za restauraciju minimalno invazivnih kaviteta I. razreda.

\section{Materijali i metode}

Eksperimentalni dizajn slijedio je smjernice Consolidated Standards of Reporting Trialsa (CONSORT) (14). Istraživanje je odobrilo Etičko povjerenstvo za klinička istraživanja (etički broj: HEK 11/40-12). Svi sudionici dobrovoljno su sudjelovali u istraživanju nakon što su potpisali informirani pristanak.

\section{Registracija protokola}

Ovo kliničko istraživanje registrirano je na ClinicalTrials. gov (NCT03556553).

\section{Eksperimentalni dizajn, postavke i mjesto prikupljanja} podataka

Provedeno je dvostruko slijepo, randomizirano i kontrolirano kliničko istraživanje u klinici Sveučilišta Hacettepe, na Odjelu za restaurativnu stomatologiju Stomatološkog fakulteta. 


\section{Recruitment}

Non-hospitalized patients were recruited in a group of as they were pursuing routine dental care.

\section{Eligibility Criteria}

A total of 63 participants were examined by two calibrated dentists to check if the participants met the inclusion and exclusion criteria (Table 1). The examinations were performed using a mouth mirror and a periodontal probe. Twenty-five patients with a mean age of 20 (range 18-25) who met the inclusion and exclusion criteria were selected. They were collected from the Restorative Dentistry Department at Hacettepe University, Faculty of Dentistry. The inclusion criteria for patients were as follows: a) being 18 years or older, b) having no medical or behavioral problems preventing from attending review treatments, c) having at least 28 teeth. The exclusion criteria were: a) poor gingival health, b) uncontrolled, rampant caries, c) bruxism, d) removable partial dentures, e) xerostomia. Clinicians carried out the assessments macroscopically with a probe and a mouth mirror when detecting fissures in need of restorations. After radiological and clinical examinations, the vitality of teeth was checked, and only superficial occlusal caries were included in the study. The inclusion criteria for the restorations were as follows: 1) having natural or crowned tooth as antagonist teeth, 2) a caries lesion scored as 3 according to ICDAS II criteria, 3) confined to occlusal pits and fissures, 4) absence of previously placed restorations. The exclusion criteria for the teeth were: 1) non-vital or previous root canal therapy 2) pulpal pathology or periapical pathology, 3) near exposures of pulp chamber on preoperative radiographs.

\section{Regrutacija/Odabir}

Uključena je skupina nehospitaliziranih pacijenata koji su tražili rutinsku stomatološku skrb.

\section{Kriteriji za uključivanje}

Dva kalibrirana doktora dentalne medicine pregledala su ukupno 63 pacijenta kako bi provjerili ispunjavaju li kriterije za uključivanje u istraživanje (tablica 1.). Pregledi su obavljeni stomatološkim zrcalom i sondom. Odabrano je dvadeset i pet pacijenata s Odjela za restaurativnu stomatologiju Stomatološkog fakulteta Sveučilišta Hacettepe, srednje dobi od 20 godina (raspon 18 - 25). Kriteriji za uključivanje pacijenata bili su sljedeći: a) da imaju 18 ili više godina; b) da su bez medicinskih ili bihevioralnih problema koji bi sprječavali odazivanje na kontrolne preglede; c) da imaju najmanje 28 zuba.

Kriteriji za isključivanje bili su: a) loše zdravlje gingive, b) nekontrolirani, prošireni karijes; c) bruksizam; d) djelomične mobilne proteze; e) kserostomija.

Kliničari su procjene obavili makroskopski s pomoću stomatološke sonde i zrcala, a tražili su fisure kojima su bile potrebne restauracije. Nakon radiološkog i kliničkog pregleda provjeren je vitalitet zuba, a u istraživanje su uključeni samo površni okluzalni karijesi.

Kriteriji za uključivanje u izradu restauracija bili su sljedeći: 1) prirodni ili zubi s krunicama kao antagonisti; 2) karijesna lezija ocijenjena ocjenom 3 prema kriterijima ICDAS-a II; 3) lezija ograničena na okluzalne fisure i jamice; 4) bez ranije postavljenih restauracija.

Kriteriji za isključivanje zuba bili su: 1) avitalni ili endodontski liječeni zubi; 2) pulpna ili periapikalna patologija; 3) blizina pulpne komore na predoperativnim rendgenskim snimkama.

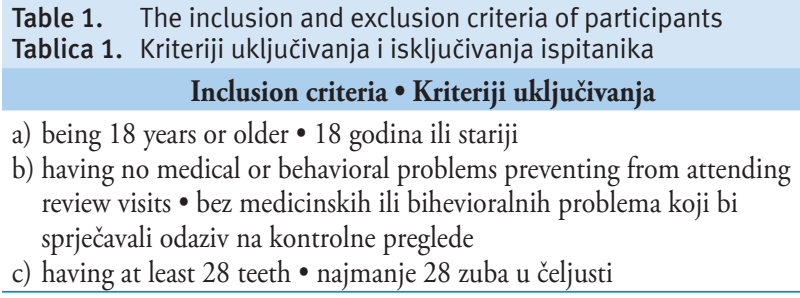

\section{Sample Size Calculation}

Considering a 5\% alpha and 90\% power value, the minimum sample size was calculated as 30 per group.

\section{Randomization}

Sixty-five restorations were performed by two-experienced clinicians. Each patient received test materials according to a table of random numbers. The teeth were randomized for each of the two experimental conditions through a table of random numbers generated by the program "Research Randomized Program" (http://www.randomizer.org/ form.htm). Clinicians performed a similar number of restorations for both groups (FDO: Vertise Flow [16], LuxaFlow [16], EE: Vertise Flow [17], LuxaFlow [16]).

\section{Kalkulacija veličine uzorka}

Uzimajući u obzir alfa vrijednost od $5 \%$ i analizu snage od $90 \%$, izračunata je najmanja veličina uzorka od 30 ispitanika po skupini.

\section{Randomizacija}

Šezdeset i pet restauracija izradila su dva iskusna kliničara. Za svakog je pacijenta slučajnim odabirom odabran jedan od dvaju testiranih materijala. Zubi su svrstani u jednu od dviju eksperimentalnih skupina s pomoću tablice slučajnih brojeva generiranih programom Research Randomized Program (http://www.randomizer.org/form.htm). Kliničari su postavili sličan broj ispuna u objema skupinama (FDO: Vertise Flow [16], LuxaFlow [16], EE: Vertise Flow [17], LuxaFlow [16]). 


\section{Restorative Procedures}

Before restorative procedures all fissures were cleaned using a rotating rubber cup adapted on a slow-speed handpiece, washed and dried, but not desiccated. The dimension of the preparation was determined by the size of the caries lesion. All included teeth had dental caries in fissure that had reached the dentin.

The materials used in the study are listed in Table 2. All teeth included in the study were molars. Cavities were prepared using diamond fissure burs (Diatech, Coltane/Whaledent AG, Altstaetten, Switzerland, 0211714) at high speed with water-cooling. The caries removal was completed using round stainless steel burs (Edenta, Liechtenstein, D02.001) on a slow-speed hand piece. Local anesthesia was applied to patients complaining about pain or sensitivity to prevent discomfort during restorative procedures. Tissue removal was terminated when the dentin was hard on probing. The prepared cavities were then randomly restored with one of the restorative systems tested.

\section{Restaurativni postupci}

Prije restaurativnog postupka sve fisure očišćene su rotirajućim gumenim polirerom u plavom kolječniku, isprane i osušene, ali ne i presušene. Dimenzija preparacije određena je prema veličini karijesne lezije. Svi uključeni zubi imali su karijes u fisuri koji je napredovao do dentina.

Materijali upotrijebljeni u istraživanju navedeni su u tablici 2. Svi zubi uključeni u istraživanje bili su kutnjaci. Kaviteti su preparirani dijamantnim fisurnim svrdlima (Diatech, Coltene/Whaledent AG, Altstaetten, Švicarska, 0211714) velikom brzinom, uz vodeno hlađenje. Uklanjanje karijesa dovršeno je okruglim svrdlom od nehrđajućeg čelika (Edenta, Lihtenštajn, D02.001) u plavom kolječniku. Lokalna anestezija primijenjena je kod pacijenata koji su se žalili na bol ili osjetljivost kako bi se spriječila nelagoda tijekom restaurativnog postupka. Uklanjanje tkiva prekinuto je kada je dentin bio tvrd na sondiranje. Preparirani kaviteti zatim su nasumično restaurirani jednim od testiranih restaurativnih materijala.

\begin{tabular}{|c|c|c|c|}
\hline $\begin{array}{c}\text { Material /Manufacturer } \\
\text { Materijal/proizvođač }\end{array}$ & $\begin{array}{l}\text { Batch No } \\
\text { Serijski br. }\end{array}$ & Composition $•$ Sastav & Application • Aplikacija \\
\hline $\begin{array}{l}\text { Vertise Flow / Kerr, } \\
\text { Orange, USA • SAD }\end{array}$ & 3413043 & $\begin{array}{l}\text { GPDM adhesive monomer, } \\
\text { UDMA, BisGMA, and other } \\
\text { methacrylate comonomers, } \\
\text { photoinitiators, fillers } 70 \% \text { by } \\
\text { weight. Ytterbium Fluoride, } \\
\text { barium aluminosilicate glass, } \\
\text { prepolymerized fillers, and } \\
\text { colloidal silica } \bullet \text { GPDM } \\
\text { adhezivni monomer, UDMA, } \\
\text { BisGMA i drugi metakrilatni } \\
\text { komonomeri, fotoinicijatori, } \\
\text { punila } 70 \% \text { mase. Iterbijev } \\
\text { fluorid, barij-aluminosilikatno } \\
\text { staklo, prepolimerizirana punila i } \\
\text { koloidna silika }\end{array}$ & $\begin{array}{l}\text { Dispense Vertise Flow in cavity with provided dispensing tip. Use } \\
\text { provided brush to apply Vertise Flow to the entire cavity wall } \\
\text { and beveled area with moderate pressure for } 15-20 \text { seconds to } \\
\text { obtain a thin layer }(<0.5 \mathrm{~mm} \text { ). Remove excess material around } \\
\text { margins with the brush if necessary. Light cure for } 20 \text { seconds. } \\
\text { After lining the cavity walls with Vertis Flow, build the restoration } \\
\text { with more Vertise Flow in increments of } 2 \text { mm or less. Light } \\
\text { cure each increment for } 20 \text { seconds } \bullet \text { Rasporediti Vertise Flow u } \\
\text { kavitetu s pomoću pripadajućeg nastavka. Upotrijebiti odgovarajuću } \\
\text { četkicu da bi se aplicirao Vertise Flow na stijenke cijelog kaviteta i } \\
\text { izravnati umjerenim pritiskom tijekom } 15-20 \text { sekunda kako bi se } \\
\text { dobio tanki sloj (<0,5 mm). Ukloniti višak materijala oko rubova } \\
\text { četkicom, ako je potrebno. Osvijetliti } 20 \text { sekunda. Nakon oblaganja } \\
\text { kaviteta Vertis Flowom, restauracija se dalje nadograđuje slojevima } \\
\text { od } 2 \text { mm ili manje. Osvijetliti svaki sloj } 20 \text { sekunda. }\end{array}$ \\
\hline $\begin{array}{l}\text { Luxa Flow / DMG, } \\
\text { Hamburg, Germany } \\
\text { Njemačka }\end{array}$ & 620342 & $\begin{array}{l}\text { Dental glass in an optimised } \\
\text { matrix made of BIS-GMA, fillers } \\
63 \mathrm{wt} \% \bullet \text { Dentalno staklo u } \\
\text { optimiziranoj matrici od BIS- } \\
\text { GMA, punila } 63 \text { mas. } \%\end{array}$ & $\begin{array}{l}\text { Place } 1 \text { increments in } 2 \mathrm{~mm} \text { or less. Light-cure for } 20 \text { seconds } \\
\text { Postavljanje jednog sloja od } 2 \mathrm{~mm} \text { ili manje. Svjetlosna } \\
\text { polimerizacija } 20 \text { sekunda ili kraće. }\end{array}$ \\
\hline
\end{tabular}

UDMA: Urethanedimethacrylate, Bis-GMA: Bisphenol A diglycidylmethacrylate, GPDM:glycerophosphate dimethacrylate UDMA: uretanedimetakrilat, Bis-GMA: bisfenol A diglicidilmetakrilat, GPDM: glicerofosfatni dimetakrilat

\section{Vertise Flow (VR) $(n=33)$}

Cavity preparations were isolated by cotton rolls and Vertise Flow was placed to the entire cavity walls. A special brush of Vertise Flow was used to apply the resine composite with a moderate pressure for 15-20 seconds to obtain a thin layer $(<0.5 \mathrm{~mm})$. Excess material was removed with the brush if necessary. Subsequently, the lining was light-cured for 20 seconds with a light curing unit (Radii Plus, SDI, Victoria, Australia). After lining the cavity, the preparation was restored with $2 \mathrm{~mm}$ or less increments of Vertise Flow. Increments were light-cured for 20 seconds with a light curing unit.

Luxa Flow (LX) ( $n=32)$

After the cavity preparation was isolated by cotton rolls, enamel was etched for 30 seconds and dentin was etched

\section{Vertise Flow (VR) $(n=33)$}

Preparirani kaviteti izolirani su pamučnim svitcima i Vertise Flow apliciran je na sve stijenke kaviteta. Posebna četkica koja se dobiva uz Vertise Flow upotrijebljena je za razmazivanje kompozita te je umjerenim pritiskom od 15 do 20 sekunda dobiven tanki sloj $(<0,5 \mathrm{~mm})$. Višak materijala uklonjen je četkicom, ako je bilo potrebno. Zatim je taj sloj svjetlosno polimeriziran 20 sekunda (Radii Plus, SDI, Victoria, Australija). Nakon oblaganja kavitet je dalje punjen u slojevima debljine $2 \mathrm{~mm}$ ili manje. Slojevi su svjetiljkom polimerizirani 20 sekunda.

\section{Luxa Flow (LX) $(\mathrm{n}=32)$}

Nakon što je kavitet izoliran pamučnim svitcima caklina je jetkana 30, a dentin 15 sekunda 37-postotnom orto- 
with 37\% phosphoric acid (Total Etch, Ivoclar Vivadent, Schaan, Liechtenstein) for 15 seconds. Then, acid was rinsed and the cavity preparation was gently dried with oil free air spray. After that, the adhesive (Teco, DMG, Hamburg, Germany) was applied to the surface using the applicator brush for 15 seconds. The adhesive was dried gently with oil free air and light-cured for 10 seconds. Afterwards, Luxa Flow was applied to the entire cavity with $2 \mathrm{~mm}$ or less increments and light-cured for 20 seconds.

The resin composite were carefully spread with a dental probe to prevent air entrapment. Light output of the curing unit was checked prior to application and ensured that it was $1200 \mathrm{~mW} / \mathrm{cm}^{2}$. An articulating paper was used to check occlusion. Finishing and polishing were performed using fine-grit diamond burs (Diatech, Swiss Dental, Switzerland) and rubber cups (Kerr Corporation, Orange, CA, USA). A total number of 65 restorations were placed in 25 patients (10 male, 14 female).

\section{Calibration for Clinical Evaluation}

Before starting the evaluations, two experienced examiners other than the operators were trained for both intra-examiner and inter-examiner reliability. For this purpose, they observed 10 photographs that were representative of each score for each criterion. Measurements of percentage agreement between the examiners were at least $85 \%$. In case of disagreement, a consensus was reached before the patients left.

\section{Blinding}

The examiners who were not involved in the restoration procedures and blinded to the group assignment performed the clinical evaluations. The subjects were also blinded to group assignment.

\section{Clinical Restorations}

Patients were evaluated at baseline (one week after restoration placement) and, every year up to 5 years after placement. The restorations were checked for retention, marginal adaptation, marginal staining, surface luster, color match, recurrence of caries and postoperative sensitivity according FDI criteria. (15) The scores were ranked as follows: (1) Clinically excellent/very good, (2) Clinically good, (3) Clinically sufficient/satisfactory, (4) Clinically unsatisfactory and (5) Clinically poor. Two experienced and calibrated examiners who did not place the restorations and were completely blind to the study protocol made the evaluations at each recall, independently using mirrors, probes and air stream. Disagreements were solved during evaluations. The examiners had to reach a consensus before the participant was dismissed. New and empty evaluation forms were filled in by the examiners to remain blinded to group assignments at recalls.

The restoration retention rates were calculated using the following equation $(16,17)$ : Cumulative failure $\%=$ $[(\mathrm{PF}+\mathrm{NF}) /(\mathrm{PF}+\mathrm{RR})] \times 100 \%$. $\mathrm{PF}$ is the number of previous failures before the current recall; NF is the number of new failures during the current recall and $R R$ is the number of restorations recalled for the current recall.

\section{Statistical Analysis}

A statistical analysis followed the intention-to-treat protocol according to CONSORT (14). Statistical analyses were performed with the IBM SPSS version 22.0 software (SPSS, fosfornom kiselinom (Total Etch, Ivoclar Vivadent, Schaan, Lihtenštajn). Zatim je kiselina isprana i kavitet je nježno osušen strujom zraka. Nakon toga je na površinu četkicom nanesen adheziv (Teco, DMG, Hamburg, Njemačka) uz 15-sekundno utrljavanje. Adheziv je lagano osušen strujom zraka i svjetlosno polimeriziran 10 sekunda. Poslije toga je Luxa Flow nanesen na cijeli kavitet u slojevima od $2 \mathrm{~mm}$ ili manje i svjetlosno polimeriziran 20 sekunda.

Kompozitne smole pažljivo su razmazane stomatološkom sondom kako bi se spriječio nastanak zračnih mjehurića. Snaga svjetiljke podešena je na $1200 \mathrm{~mW} / \mathrm{cm}^{2}$. Okluzija je provjerena artikulacijskim papirom. Za završnu obradu i poliranje upotrijebljena su sitnozrnata dijamantna svrdla (Diatech, Swiss Dental, Švicarska) i gumeni polireri (Kerr Corporation, Orange, CA, SAD). Postavljeno je ukupno 65 restauracija desetorici muškaraca i četrnaest žena (ukupno 25 pacijenata).

\section{Kalibracija za kliničku procjenu}

Prije početka procjene dva iskusna istraživača, osim kliničara, kalibrirana su kako bi se osigurala ponovljivost unutar ispitivača i između njih. U tu svrhu gledali su 10 fotografija koje su bile reprezentativne za svaku ocjenu za svaki kriterij. Podudaranje između istraživača iznosilo je najmanje 85 $\%$. U slučaju neslaganja postignut je konsenzus prije otpuštanja pacijenata.

\section{Zasljepljivljanje}

Kliničku procjenu obavili su istraživači koji nisu bili uključeni u restaurativne postupke i nisu znali kojoj skupini pripada koja restauracija. Ispitanici također nisu znali u koju su skupinu uvršteni.

\section{Klinička procjena}

Pacijenti su procijenjeni na početku (tjedan dana nakon restauracije) i jedanput svake godine u petogodišnjem razdoblju nakon opskrbe. Restauracije su provjerene s obzirom na retenciju, rubnu prilagodbu, rubno obojenje, površinski sjaj, podudaranje boje, recidiv karijesa i postoperativnu osjetljivost prema kriterijima FDI-a (15). Ocjene su rangirane na sljedeći način: 1) klinički odličan/vrlo dobar; 2) klinički dobar; 3) klinički dovoljan/zadovoljavajući; 4) klinički nezadovoljavajući; 5) klinički loš.

Dva iskusna i kalibrirana istraživača, koji nisu postavljali restauracije i nisu bili upućeni u protokol istraživanja, neovisno su procjenjivali restauracije pri svakom pregledu primjenom zrcala, sonde i struje zraka. Neslaganja su riješena tijekom evaluacije. Ispitivači su morali postići konsenzus prije otpuštanja pacijenta. Također su ispunjavali nove i prazne obrasce za ocjenjivanje kako bi ostali zaslijepljeni na kontrolnim pregledima.

Stope retencije restauracija izračunate su sljedećom jednadžbom $(16,17)$ : kumulativni neuspjeh $\%=[(\mathrm{PF}+\mathrm{NF}) /$ $(\mathrm{PF}+\mathrm{RR})] \times 100 \%$.

$\mathrm{PF}$ je broj prethodnih neuspjeha prije aktualne kontrole; NF je broj novih neuspjeha tijekom aktualne kontrole, a RR je broj kontrolnih pregleda.

\section{Statistička analiza}

Statistička analiza bila je u skladu s protokolom o namjeri liječenja prema CONSORT-u (14). Statističke analize obavljene su u softveru IBM SPSS 22.0 (SPSS, Chicago, IL, 
Chicago, IL, USA). The Pearson Chi-Square tests were used to compare two restorative materials and define frequency distributions of the evaluated criteria. The differences in the ratings of the two materials were tested after 1, 2, 3, 4, 5 years. The changes across different time points within each restorative material were analyzed by the Cochran Q-test followed by the Mc Nemar's tests. The level of significance was set at $p<0.05$ for all tests.

\section{Results}

The recall rates were $96 \%, 80 \%, 76 \%, 72 \%, 68 \%$ for 1 , 2, 3, 4 and 5-year evaluations, respectively. None of the restorations showed postoperative sensitivity and recurrence of caries at any evaluation (Table 2, Figure 1).

\section{Overall retention}

The retention rates were $100 \%$ for both materials at 1-year assessments. At 2-year recall $2 \mathrm{VR}$ and $1 \mathrm{LX}$ restorations were lost. No retention lost was detected at 3-year evaluations, but $1 \mathrm{VR}$ and $1 \mathrm{LX}$ restoration were lost at 4-year assessments. After 5 years the cumulative failure rates for retention were $15.3 \%$ (4 restorations) for VR and 7.6\% (2 restorations) for LX group (Table 3) ( $>0.05)$.

\section{Marginal adaptation}

At 1-year assessments, 13 VR (41.9\%) and 11 LX (37.5\%) restorations exhibited minor discrepancies which were scored
SAD). Za usporedbu dvaju restaurativnih materijala i definiranje frekvencijskih distribucija ocijenjenih kriterija primijenjen je Pearsonov hi-kvadrat test. Razlike u ocjenama dvaju materijala analizirane su nakon jedne, dvije, tri, četiri i pet godina. Promjene u različitim vremenskim točkama unutar svakog restaurativnog materijala analizirane su Cochranovim Q-testom, a zatim Mc-Nemarovim testovima. Razina značajnosti za sve testove postavljena je na $\mathrm{p}<0,05$.

\section{Rezultati}

Stope odaziva na kontrolne preglede bile su $96 \%, 80 \%$, $76 \%, 72 \%, 68 \%$ nakon jedne, dvije, tri, četiri i pet godina. $\mathrm{Ni}$ za jednu restauraciju nisu zabilježeni postoperativna osjetljivost i recidivi karijesa ni u jednoj vremenskoj točki (tablica 2., slika 1.).

\section{Ukupna retencija}

Stope retencije iznosile su $100 \%$ za oba materijala pri procjeni nakon jedne godine. Na kontrolnom pregledu nakon dvije godine ustanovljen je gubitak dviju restauracija iz skupine VR i jedne iz skupine LX. Na trogodišnjoj procjeni nisu zabilježeni gubitci retencije. Nakon četiri godine izgubljena je po jedna restauracija iz skupina VR i LX. Nakon pet godina kumulativne stope gubitka retencije bile su 15,3 \% (4 restauracije) u skupini VR i 7,6 \% (2 restauracije) u skupini LX (tablica 3.) ( $p>0,05)$.

\section{Rubna prilagodba}

Na pregledu nakon godinu dana 13 restauracija iz skupine VR (41,9 \%) i 11 iz skupine LX (37,5 \%) pokazalo je ma-

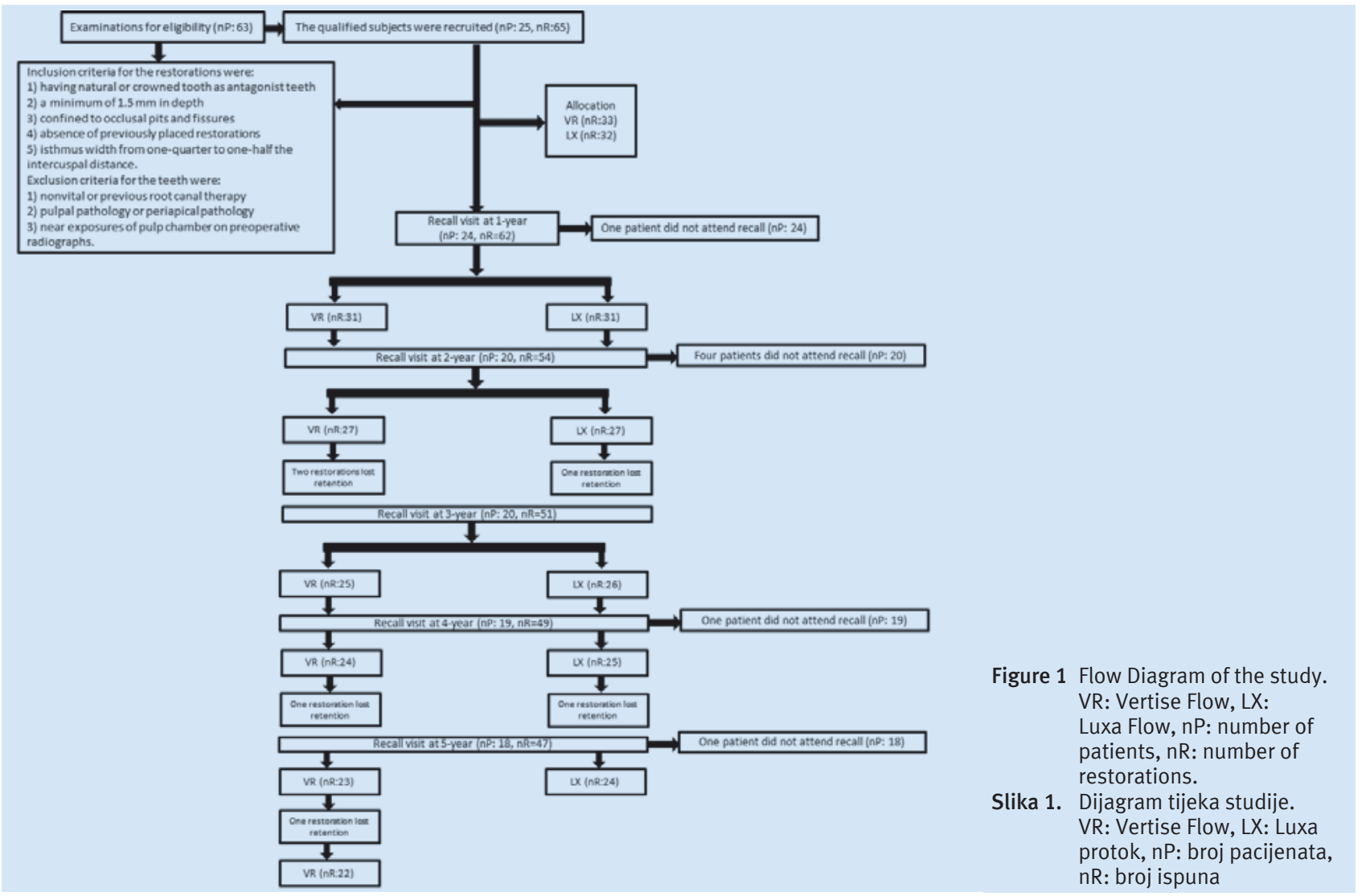


Table 3. Clinical evaluation outcomes of different restorations

Tablica 3. Procjena kliničkih rezultata različitih restauracija

Evaluation criteria $\bullet$ Kriterij procjene

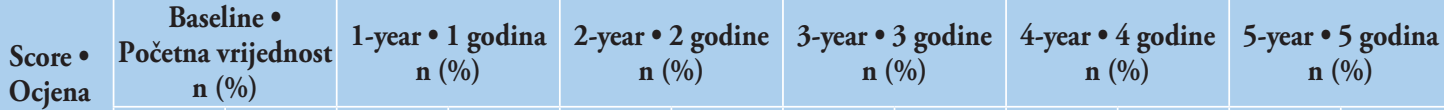
\begin{tabular}{l|l|l|l|l|l|l|l|l|l|l} 
VR (33) LX (32) VR (31) & LX (31) VR (27) & LX (27) & VR (25) & LX (26) & VR (24) & LX (25) VR (23) LX (24)
\end{tabular}

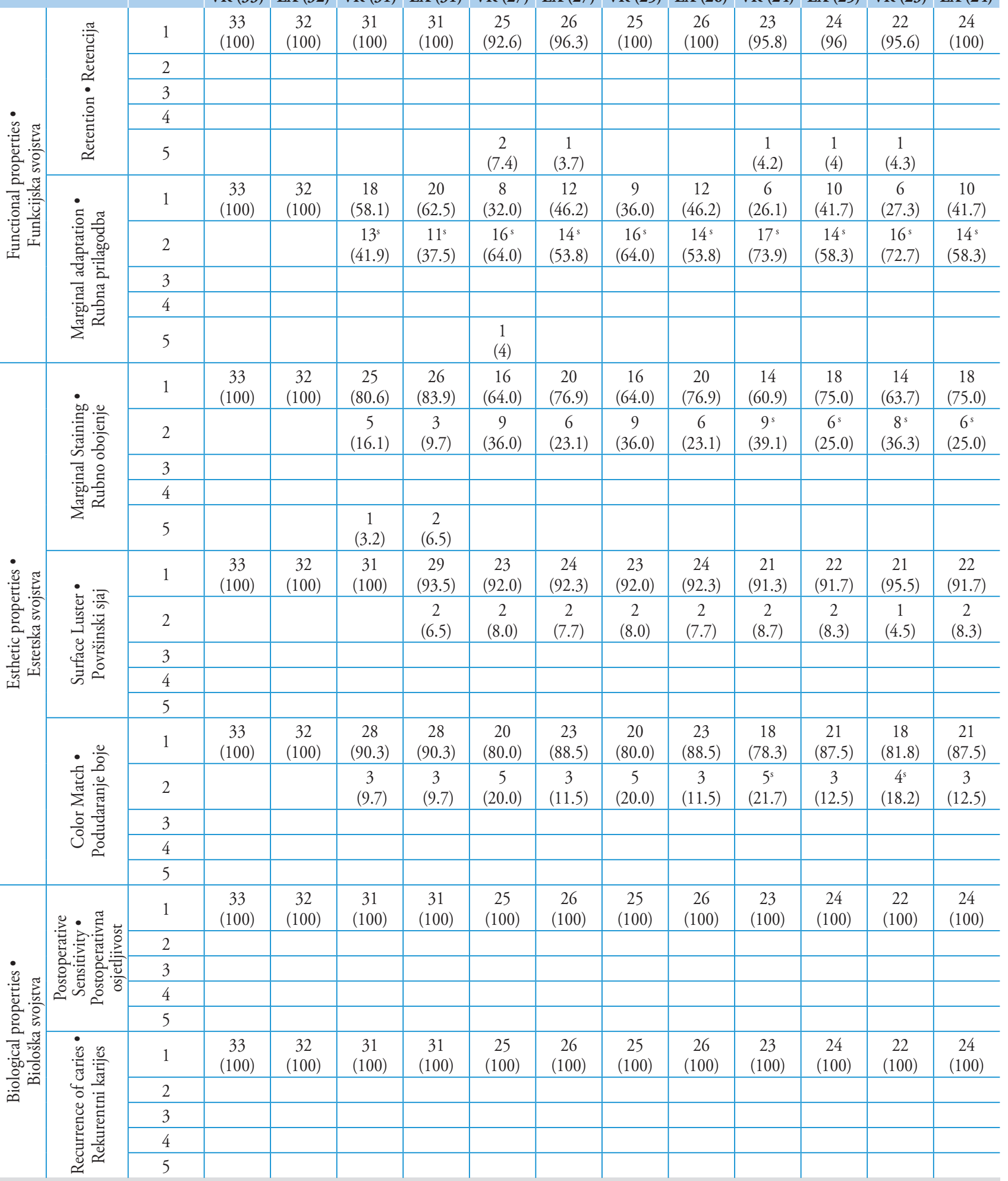

'Indicates significant difference in comparison with baseline according to Cochran's Q test fallowed by McNemar's test $(\mathrm{p}<0.05)$ VR: Vertise Flow, LX: Luxa Flow. The outcomes were scored as follows: (1) clinically excellent/very good, (2) clinically good, (3) clinically sufficient/satisfactory, (4) clinically unsatisfactory, and (5) clinically poor.

sUpućuje na statistički značajnu razliku u usporedbi s početnom vrijednošću prema Cochranovu Q-testu i McNemarovu testu $(p<0,05)$ VR: Vertise Flow, LX: Luxa Flow. Rezultati su ocijenjeni sljedećim ocjenama: (1) klinički izvrsno/vrlo dobro, (2) klinički dobro, (3) klinički zadovoljavajuće, (4) klinički nezadovoljavajuće i (5) klinički loše. 
Table 4. Relative cumulative frequencies (\%) of lost restorations during 5-year follow-up

Tablica 4. Relativne kumulativne frekvencije (\%) gubitka restauracija tijekom razdoblja praćenja od 5 godina

\begin{tabular}{l|c|c|c|c|} 
& 2-year $\bullet$ 2 godine & 3-year $\bullet \mathbf{3}$ godine & 4-year $\bullet$ 4 godine \\
Vertise Flow & 7.4 & 7.4 & 11.5 & 15.3 \\
\hline LuxaFlow & 3.7 & 3.7 & 7.6
\end{tabular}

No significant difference were observed between groups when compared to baseline according to Cochran’s Q test $(p<0.05) \bullet$ Nisu zabilježene statistički značajne razlike između skupina u usporedbi s početnim vrijednostima prema Cochranovu Q-testu $(p<0,05)$

as clinically good (2). At 2-year evaluations, 16 VR (64\%) restorations and $14 \mathrm{LX}(53.8 \%)$ restorations scored as clinically good $(2)(p<0.05)$ and only 1 VR restoration $(3.8 \%)$ scored clinically poor (5). After 3 years 16 VR (64\%) and $14 \mathrm{LX}(53.8 \%)$ restorations scored as clinically good (2). At 4-year examinations, 17 VR (73.9) and $14 \mathrm{LX}$ (53.8) showed clinically good (2) score. At the end of 5 years, 6 VR restorations (27.3\%) and $10 \mathrm{LX}(41.7 \%)$ restorations demonstrated clinically very good (1) scores, which was not statistically significant $(p>0.05)$.

\section{Marginal staining}

At 1-year evaluations, 5 VR (16.1\%) and 3 LX (9.7\%) the restorations demonstrated minor marginal staining which were scored as clinically good (2). One (3.2\%) VR and $2(6.5 \%)$ LX restorations scored as clinically poor (5). At 2-year examinations, $9 \mathrm{VR}$ restorations (36\%) and $6 \mathrm{LX}$ $(23.1 \%)$ restorations were scored as clinically good (2) ( $p>$ $0.05)$. At 3 -year assessments, 9 VR (36\%) restorations and 6 LX (23.1\%) restorations were scored as clinically good (2). At the end of 5 years, 14 VR (63.7\%) restorations and 18 LX (75\%) restorations exhibited very good clinical (1) scores, which was not statistically significant $(p<0.05)$.

\section{Surface luster}

At 1-year examinations, all of VR restorations showed very good clinical (1) scores, however 2 LX (6.5\%) restorations exhibited good clinical (2) scores. At 2-year evaluations, 2 VR $(7.7 \%)$ restorations and 2 LX (8\%) were restorations scored as clinically good (2). After 4 years, most of the restorations [VR: 91.3\%, LX: 91.7\%] in both groups exhibited very good clinical scores (1). At the end of 5 years, $1 \mathrm{VR}$ $(4.5 \%)$ restoration and $2 \mathrm{LX}(8.3 \%)$ restorations demonstrated good clinical (2) scores, whereas the rest of the restorations were excellent (score 1) for the criteria assessed. No significant difference was detected for surface luster at any time interval $(p>0.05)$.

\section{Color match}

Three VR and 3 LX restorations scored as clinically good (2) at 1-year [VR: 9.7\%, LX: 9.7\%]. At 2-year assessments, 5 VR (20\%) and 3 LX (11.5\%) scored as clinically good (2). At the end of 5 years, 4 VR (18.2) and 3 LX (12.5\%) restorations scored as clinically good (2) and the differences were not statistically significant $(p>0.05)$.

The McNemar's test showed a significant change in marginal adaptation in VR and LX groups at all evaluated points $(1,2,3,4,5$-year) compared to baseline $(p<0.001)$. Besides, nja odstupanja koja su ocijenjena kao klinički dobra (2). Tijekom dvogodišnje procjene 16 restauracija iz skupine VR (64 \%) i 14 iz supine LX (53,8 \%) ocijenjeno je klinički dobrima (2) $(\mathrm{p}<0,05)$, a samo jedna u skupini VR $(3,8 \%)$ kao klinički loša (5). Nakon tri godine 16 restauracija u skupini VR (64 \%) i 14 u skupini LX (53,8 \%) ocijenjeno je klinički dobrima (2). Nakon četiri godine 17 restauracija u skupini VR $(73,9)$ i 14 u skupini LX $(53,8)$ pokazalo je klinički dobar $(2)$ rezultat. Poslije pet godina šest restauracija u skupini VR $(27,3 \%)$ i 10 u skupini LX (41,7\%) pokazalo je klinički vrlo dobre (1) rezultate koji nisu bili statistički značajni $(\mathrm{p}>0,05)$.

\section{Rubno obojenje}

Pri procjeni nakon godinu dana na pet restauracija iz skupine VR (16,1 \%) i tri iz skupine LX (9,7 \%) zabilježena su rubna obojenja koja su ocijenjena ocjenom klinički dobar (2). Jedna restauracija iz skupine VR (3,2\%) i dvije iz skupine LX $(6,5 \%)$ ocijenjene su kao klinički loše (5). Nakon dvije godine devet restauracija iz skupine VR (36\%) i šest iz skupine LX (23,1\%) ocijenjeno je klinički dobrima (2) ( $p>0,05)$. Nakon tri godine devet restauracija iz skupine VR (36 \%) i šest iz skupine LX (23,1\%) ocijenjeno je klinički dobrima (2). Nakon pet godina 14 restauracija iz skupine VR $(63,7$ \%) i 18 iz skupine LX (75\%) dobilo je ocjenu klinički vrlo dobar (1), što nije bilo statistički značajno $(\mathrm{p}<0,05)$.

\section{Površinski sjaj}

Na pregledu nakon jedne godine sve restauracije iz skupine VR pokazale su klinički vrlo dobar (1) rezultat, a dvije iz skupine LX (6,5\%) pokazale su klinički dobar (2) rezultat. Nakon dvije godine dvije restauracije iz skupine VR $(7,7 \%)$ i dvije iz skupine LX (8 \%) ocijenjene su kao klinički dobre (2). Nakon četiri godine većina restauracija (VR: $91,3 \%$, LX: $91,7 \%$ u objema skupinama imala je klinički vrlo dobre (1) rezultate. Nakon pet godina jedna restauracija iz skupine VR $(4,5 \%)$ i dvije iz skupine LX (8,3\%) pokazale su klinički dobre (2) rezultate, a ostale bile su izvrsne (ocjena 1) za procijenjeni kriterij. Ni u jednoj vremenskoj točki nije uočena značajna razlika u površinskom sjaju ( $\mathrm{p}>0,05)$.

\section{Podudaranje boje}

Po tri restauracije iz skupina VR i LX ocijenjene su kao klinički dobre (2) nakon jedne godine (VR: 9,7\%, LX: 9,7 $\%)$. Nakon dvije godine pet restauracija iz skupine VR (20\%) i tri iz skupine LX (11,5\%) ocijenjene su klinički dobrima (2). Nakon pet godina četiri restauracije iz skupine VR $(18,2)$ $i$ tri iz skupine LX (12,5\%) ocijenjene su kao klinički dobre (2), a razlike nisu bile statistički značajne ( $p>0,05)$.

McNemarov test pokazao je značajnu promjenu rubne prilagodbe u skupinama VR i LX u svim vremenskim točka- 
both materials showed significant changes starting from 4 -year regarding marginal staining $(p<0.001)$. The color match of VR exhibited significant changes after 4 and 5-year evaluations compared to baseline. $(p<0.001)$.

\section{Discussion}

Clinical trials conducted with minimal occlusal restorations mostly involve children. In this case, the application becomes harder to perform and a good enamel bonding is crucial for these restorations to survive. Besides, the parents have to be willing to bring their children for follow-up and cooperation can be difficult to achieve. In the present study, the participants older than 18 were selected, hence the cooperation and follow-up were easier to achieve. The recall rate was $68 \%$ and the follow-up was considered acceptable after 5 years.

Vertise Flow was manufactured to combine a self-etch system to the flowable resin composite. The bonding mechanism is a chemical bonding produced via glycerophosphate dimethacrylate (GPDM) between phosphate functional groups of GPDM monomers and calcium ions of enamel and dentin (18). To reduce steps at restorative applications, the formulation of this self-adhering composite resin was developed as the combination of prime, bond and resin composite. The elimination of multiple steps is required for easy application and short application time, particularly in young patients with behavioral problems and children.

An in vitro study (13) showed that Vertise Flow resulted in lower bond strength values when compared with all-in-one adhesive systems. However, the first clinical study published (19) regarding Vertise Flow suggested that after 6-month, the Vertise Flow exhibited acceptable results and no retention loss was reported. Similarly, the present study showed no retention loss at 1 -year examination. However, after 5 years, 5 restorations lost retention (15.3\%). Kucukyllmaz et. al. (12) compared Vertise Flow with two types of fissure sealants and a flowable resin composite with an adhesive system. The flowable resin composite used with an adhesive system exhibited higher retention rates $(95.7 \%)$ than other sealing materials. The retention rate of Vertise Flow was the lowest (62.9\%) after 2-year evaluation. Conversely, in the present study, it was found that the conventionally applied flowable resin composite LuxaFlow with an etch\&rinse system showed similar results to Vertise Flow. Therefore, the null hypothesis was accepted.

In this study the FDI evaluation criteria were used since they are more sensitive to small variations in the clinical outcomes compared with the USPHS criteria. (15) Minor deviatons are scored differently from excellent restorations. This might explain the high (2) scores regarding marginal adaptation and marginal discoloration of both groups after 5 -year assessments. Kitasako et al. (20) evaluated two different type of flowable resin composite placed using a two-step self-etch adhesive with FDI criteria, and concluded that tested groups had similar clinical outcome at 3-year follow-up.

The addition of a self-etch adhesive to the resin composite might have adverse effects on physical properties of the flow- ma (nakon 1, 2, 3, 4 i 5 godina) u odnosu prema početnoj vrijednosti $(\mathrm{p}<0,001)$. Uz to, oba su materijala pokazala značajne promjene parametra rubno obojenje nakon četiri godine ( $\mathrm{p}<0,001)$. Podudaranje boje u skupini VR pokazalo je značajne promjene nakon četiri i pet godina u usporedbi s početnom vrijednosti $(\mathrm{p}<0,001)$.

\section{Rasprava}

U klinička istraživanja s minimalno invazivnim okluzalnim restauracijama uglavnom su uključena djeca. U tom slučaju aplikacija je složenija, a dobro prianjanje na caklinu presudno je za opstanak tih restauracija. Uz to, roditelji moraju biti spremni dovesti djecu na praćenje i kontrole, pa suradnja može biti otežana. U ovom istraživanju odabrani su sudionici stariji od 18 godina kako bi suradnja i praćenje bili jednostavniji. Stopa odaziva na kontrolne preglede bila je $68 \%$, što se nakon pet godina smatralo prihvatljivim.

Vertise Flow proizveden je kao kombinacija samojetkajućeg adheziva i tekućeg kompozita. Mehanizam vezivanja je kemijska veza ostvarena preko glicerofosfat-dimetakrilata (GPDM) između fosfatnih funkcijskih skupina GPDM monomera i kalcijevih iona cakline i dentina (18). Kako bi se smanjio broj koraka u restaurativnom postupku, formulacija toga samoadhezivnog kompozitnog materijala razvijena je kao kombinacija primera, bonda i kompozitne smole. Posebno kad je riječ o mladim pacijentima s poremećajima u ponašanju i djece, smanjenje broja koraka nužno je kako bi se pojednostavnila aplikacija i skratilo vrijeme primjene.

Istraživanje in vitro (13) pokazalo je da Vertise Flow postiže niže vrijednosti vezne čvrstoće u usporedbi s adhezivnim sustavima sve-u-jednome. No prvo objavljeno kliničko istraživanje (19) o Vertise Flowu upućuje na to da nakon šest mjeseci taj materijal pokazuje prihvatljive rezultate i da nije zabilježen gubitak retencije. Slično tomu, u ovom istraživanju nije zabilježen gubitak retencije na pregledu nakon godine dana. No poslije pet godina na pet restauracija dogodio se gubitak retencije $(15,3 \%)$. Kucukyllmaz i suradnici (12) uspoređivali su Vertise Flow s dvjema vrstama smola za pečaćenje fisura i tekućim kompozitom koji se primjenjuje u kombinaciji s adhezivnim sustavom. Tekući kompozit u kombinaciji $s$ adhezivnim sustavom postigao je veće stope retencije (95,7 $\%)$ u odnosu prema ostalim materijalima za pečaćenje. Stopa retencije Vertise Flowa bila je najniža $(62,9 \%)$ na procjeni nakon dvije godine. Suprotno tomu, u ovom je istraživanju utvrđeno da je konvencionalni tekući kompozit LuxaFlow s jetkajuće-ispirućim adhezivnim sustavom postigao slične rezultate kao Vertise Flow. Dakle, nulta hipoteza je prihvaćena.

$\mathrm{U}$ ovom su istraživanju primijenjeni kriteriji FDI-a jer su osjetljiviji na male varijacije u kliničkim rezultatima u usporedbi s kriterijima USPHS-a. (15) Manje razlike ocjenjuju se drukčije na izvrsnim restauracijama. To bi moglo objasniti visoke (2) ocjene u vezi s rubnom prilagodbom i rubnom promjenom boje u objema skupinama nakon pet godina. Kitasako i suradnici (20) procijenili su dvije različite vrste tekućih kompozita apliciranih uz samojetkajući adheziv u dva koraka prema kriterijima FDI-a i zaključili da su obje skupine imale sličan klinički ishod tijekom trogodišnjeg praćenja. 
able resin composite. Hydrophilic monomers in the self-adhering restorative material can be the reason for unstable dimensions of composite resin (21). The filler content of Vertise Flow (wt 70\%) and LuxaFlow (wt 63\%) by weight is similar according to manufacturers, therefore mechanical and physical behaviors are expected to be similar. Clinical trials conducted using self-etch adhesives have demonstrated that their long-term stability is questionable compared to etch\&rinse adhesive systems (22-24). However, the result of this clinical investigation showed similar outcomes considering the properties of the restorative materials. Flowable composites are thought to have greater polymerization shrinkage than conventional packable composites (25). Consequently, an increased rate for marginal discoloration, marginal adaptation and secondary caries is expected. However, a clinical study reported that, after two years, a flowable composite showed the results that were similar to a conventional resin composite (26). In the present study, after 5 years, the flowable composites exhibited similar results. Consequently, it could be speculated that the stress between the composite and the tooth is not sufficient to separate the restoration. Furthermore, lower modulus of elasticity might result in reduced stress at the adhesive interface $(6,27)$. Although it is possible that marginal gaps get wider over some time, a study has demonstrated that in a wet environment polymerization stresses may relax over time (28).

The acidity of self-etch adhesives varies and $\mathrm{pH}$ might have an effect on clinical performances. A systematic review (29) on the clinical performance of adhesives suggested that mild two-step self-etch adhesives showed the best clinical bonding effectiveness. On the other hand, strong self-etch $(\mathrm{pH}<1.5)$ and two-step etch-and-rinse adhesives were shown to exhibit unfavorable results. Vertise Flow has a $\mathrm{pH}$ level of 1.9, which is classified as mild, (30) but no significant difference was detected between two restorative materials clinically. The adhesive system used in the LuxaFlow group (Teco) is an acetone free adhesive. Also, Vertise Flow was used with the Optibond self-etch technology according to the manufacturer's instructions, which is an ethanol, based adhesive system. Although etch\&rinse adhesives are expected to have superior results than self-etch systems $(22,23)$, in the present study, Vertise Flow and LuxaFlow exhibited similar clinical outcomes after 5 years. However, Sabbagh et al. (31) showed that Vertise Flow and Premise Flowable used with a self-adhesive resin system exhibited similar clinical findings and both groups demonstrated a decrease in alpha scores over time. Some previous clinical trials $(12,32)$ had compared flowable resin composite to fissure sealants at pit and fissures and reported to have superior clinical results. In the present study, the self-adhering flowable resin composite obtained the results which were similar to a flowable resin composite when applied by the use of an etch\&rinse adhesive.

The penetration of the flowable resin composite is another important factor for success. An in vitro study reported that enamel etching enhanced the penetration capacity of self-adhesive resin composites and recommended selective etching before Vertise Flow. (33) Kucukyilmaz et al. (12) reported that Vertise Flow demonstrated satisfactory results after 24-month. They mentioned that out of 40 Vertise Flow restorations, only two showed Bravo scores and one Charlie score for marginal discoloration and integrity.
Dodavanje samojetkajućeg adheziva kompozitnoj smoli može negativno utjecati na fizikalna svojstva materijala. Hidrofilni monomeri u samoadhezivnom restaurativnom materijalu mogu biti razlog nestabilnih dimenzija kompozitne smole (21). Sadržaj punila Vertise Flowa (maseni udio $70 \%$ ) i LuxaFlowa (maseni udio $63 \%$ ) sličan je prema navodima proizvođača, pa se očekuje da su i mehanička i fizikalna svojstva slična. Klinička istraživanja provedena sa samojetkajućim adhezivima pokazala su da je njihova dugoročna stabilnost upitna u usporedbi s jetkajuće-ispirućim adhezivnim sustavima $(22-24)$. Međutim, rezultati ovoga kliničkog istraživanja bili su slični s obzirom na svojstva restaurativnih materijala. Smatra se da tekući kompoziti imaju veću kontrakciju u usporedbi s onima konvencionalnima u obliku paste (25). U skladu s tim, očekuju se češće rubne promjene boje, lošija rubna prilagodba i sekundarni karijes. No u jednom kliničkom istraživanju istaknuto je da je nakon dvije godine tekući kompozit imao slične rezultate kao konvencionalni (26). U ovom su istraživanju nakon pet godina tekući kompoziti pokazali slične rezultate. Dakle, moglo bi se pretpostaviti da naprezanje između kompozita i zuba nije dovoljno za razdvajanje restauracije. Nadalje, niži modul elastičnosti može rezultirati smanjenim naprezanjem na sučelju materijala $(6$, 27). Iako se granične pukotine $s$ vremenom mogu povećati, $\mathrm{u}$ jednom je istraživanju istaknuto da se u vlažnom okružju polimerizacijsko naprezanje $s$ vremenom može smanjiti (28).

Kiselost samojetkajućih adheziva je različita, a pH može utjecati na kliničke performanse. Sistematizirani pregledni rad (29) o kliničkoj učinkovitosti adheziva pokazao je da blagi samojetkajući adhezivi u dva koraka imaju najbolju kliničku učinkovitost. Istodobno, jaki samojetkajući adhezivi ( $\mathrm{pH}$ $<1,5)$ i jetkajuće-ispirući adhezivi u dva koraka pokazuju neadekvatne rezultate. PH vrijednost Vertise Flowa iznosi 1,9 što je klasificirano kao blago (30), ali nije utvrđena značajna razlika između dvaju restaurativnih materijala. Adhezivni sustav koji je upotrijebljen u skupini LuxaFlow (Teco) jest adheziv bez acetona. Vertise Flow također je korišsten uz Optibond samojetkajuću tehniku prema uputama proizvođača, a riječ je o adhezivnom sustavu na bazi etanola. Iako se očekuje da jetkajuće-ispirući adhezivi imaju bolje rezultate u odnosu prema samojetkajućim sustavima $(22,23)$, u ovom su istraživanju Vertise Flow i LuxaFlow pokazali slične kliničke rezultate nakon pet godina. No Sabbagh i suradnici (31) pokazali su da Vertise Flow i Premise Flowable imaju slične kliničke nalaze i u objema skupinama smanjila se tijekom vremena vrijednost alfa. U nekim dosadašnjim kliničkim istraživanjima $(12,32)$ uspoređivali su se tekući kompoziti sa smolama za pečaćenje i pokazali su bolje kliničke rezultate kompozita. U ovom istraživanju samoadhezivni tekući kompoziti imali su slične rezultate kao i konvencionalni koji su primijenjeni u kombinaciji s jetkajuće-ispirućim adhezivom.

Penetracija tekućih kompozita još je jedan važan čimbenik uspjeha. $\mathrm{U}$ istraživanju in vitro istaknuto je da jetkanje cakline povećava prodiranje samoadhezivnih kompozita i preporučeno je selektivno jetkanje prije Vertise Flowa (33). Kucukyilmaz i suradnici (12) izvijestili su da je Vertise Flow postigao zadovoljavajuće rezultate nakon 24 mjeseca. Spomenuli su da su od 40 restauracija s Vertise Flowom samo dvije dobile ocjenu Bravo i jedna ocjenu Charlie za rubnu promjenu boje i integritet. 
One year or two years are short periods to evaluate the clinical performance of dental restorative materials. Longterm clinical studies are needed to validate these findings. The choice of restorative material for superficial Class I cavities should be determined by the long-term performance of resin composites. Therefore, the restoration of superficial Class I cavities with flowable resin composite must be carefully and continuously reviewed by periodic follow-ups to detect failures and to obtain more reliable results.

\section{Conclusion}

Within the limitations of this clinical trial, it can be concluded that the self-adhering flowable (Vertise Flow) and the conventional flowable resin composite used with an etch\&rinse system have similar clinical performance at 5-year follow-up period. Both materials showed some degradation over time regarding marginal adaptation and marginal discoloration.

\section{Conflict of interest}

The authors declare no conflict of interest.

\section{Funding}

No funding

\section{Ethical approval}

All procedures performed in studies involving human participants were in accordance with the ethical standards of the institutional and/or national research committee and with the 1964 Helsinki Declaration and its later amendments or comparable ethical standards.

\section{Informed consent}

Informed consent was obtained from all individual participants included in the study.
Jedna ili dvije godine kratka su razdoblja za procjenu kliničke učinkovitosti dentalnih restaurativnih materijala. Za validaciju tih nalaza potrebna su dugoročna klinička istraživanja. Izbor restaurativnog materijala za površinske kavitete I. razreda treba ovisiti o dugoročnim rezultatima kompozitnih materijala. Stoga se restauracije površinskih lezija I. razreda s tekućim kompozitima moraju pažljivo pregledavati i kontinuirano povremeno pratiti radi pravodobnog otkrivanja defekata.

\section{Zaključak}

Uzimajući u obzir ograničenja ovoga kliničkog istraživanja, može se zaključiti da su samoadhezivni tekući kompozit (Vertise Flow) i konvencionalni tekući kompozit u kombinaciji s jetkajuće-ispirućim sustavom imali slične kliničke rezultate u petogodišnjem razdoblju praćenja. Kod oba materijala tijekom vremena se dogodila degredacija u rubnoj prilagodbi i rubnoj promjeni boje.

\section{Sukob interesa}

Autori navode da nisu bili u sukobu interesa.

\section{Financiranje}

Istraživanje nije financirano.

\section{Etičko odobrenje}

Svi postupci u ovom istraživanju koji su uključivali ljude provedeni su u skladu s etičkim standardima institucijskog i/ ili nacionalnog istraživačkog odbora i Helsinškoj deklaraciji iz 1964. i kasnijim amandmanima ili sličnim etičkim standardima.

\section{Informirani pristanak}

Informirani pristanak potpisali su svi ispitanici.
Sažetak

Svrha istraživanja: Cilj ovog istraživanja bio je procijeniti dugoročne kliničke rezultate samoadhezivnog tekućeg kompozita u usporedbi s konvencionalnim tekućim kompozitom u kombinaciji s jetkajuće-ispirućim adhezivom u minimalno invazivnim kavitetima I. razreda. Materijali i metode: Na zubima dvadeset i pet pacijenata izrađena su barem po dva ispuna I. razreda $(n=65)$. Nakon što su preparirani kaviteti I. razreda, nasumično su restaurirani ili samoadhezivnim tekućim kompozitom (VertiseFlow/Kerr-VR) [skupina $1(n=33)$ ], ili konvencionalnim tekućim kompozitom (Luxaflow/DMG-LX) u kombinaciji s jetkajuće-ispirućim adhezivnim sustavom (Teco/DMG) [skupina $2(\mathrm{n}=32)$ ] prema uputama proizvođača. Dva istraživača procijenila su početne vrijednosti restauracija prema kriterijima FDI-a i nakon toga u petogodišnjem razdoblju jedanput na godinu. Statistička analiza provedena je Pearsonovim Chi-kvadrat testom i Cochranovim Q-testom, a zatim McNemarovim testom $(p=0,05)$. Rezultati: Nakon pet godina ukupno je izrađeno 47 restauracija sa stopom odaziva na kontrolne preglede od $68 \%$. U razdoblju od četiri godine, na trima $(11,5 \%)$ restauracijama u skupini VR i dvjema u skupini LX $(7,6 \%)$ dogodio se kumulativni gubitak retencije. Sedamnaest restauracija $(73,9 \%)$ VR i 14 LX (58,3 $\%$ ) ocijenjeno je klinički dobrima (2) za parametar rubne prilagodbe. Pri procjeni nakon pet godina u skupinama VR i LX zabilježeni su slični rezultati za sve procijenjene parametre $(p>0,05)$. Kumulativne stope gubitka retencije u skupinama VR i LX iznosile su 15,3\%, odnosno 7,6 \%. Ni kod jedne restauracije nije zabilježen rekurentni karijes ili postoperativna osjetljivost. Za oba materijala zabilježena je značajna promjena nakon četiri i pet godina, kad je riječ o rubnom obojenju, u odnosu prema početnoj vrijednosti $(p<0,001)$. Nadalje, opažene su značajne promjene za parametar rubne prilagodbe $u$ skupinama VR i LX nakon jedne, dvije, tri, četiri i pet godina u usporedbi s početnom vrijednosti $(p<$ 0,001). Zaključak: Oba materijala za restauraciju kaviteta I. razreda pokazala su klinički prihvatljive rezultate nakon pet godina. Samoadhezivni tekući kompozit imao je slične kliničke performanse kao i konvencionalni tekući kompozit u kombinaciji s jetkajuće-ispirućim adhezivnim sustavom.
Zaprimljen: 12. siječnja 2020. Prihvaćen: 1. ožujka 2020.

Adresa za dopisivanje Fatma Dilsad Oz, DDS, PhD Hacettepe University, School of Dentistry Department of Restorative Dentistry, Sihhiye, 06100, Ankara, TURKEY tel: +903123052270 faks: +903123113438 dilsadoz@yahoo.com

Ključne riječi

trajni zubni ispun; kompozitne smole; prionjivost; rubno prianjanje materijala za punjenje 


\section{References}

1. Feigal RJ. Sealants and preventive restorations: review of effectiveness and clinical changes for improvement. Pediatr Dent. 1998 Mar-Apr;20(2):85-92.

2. Gilpatrick RO, Ross JA, Simonsen RJ. Resin-to-enamel bond strengths with various etching times. Quintessence Int. 1991 Jan;22(1):47-9.

3. Ripa LW. Occlusal sealants: rationale and review of clinical trials. Int Dent J. 1980 Jun;30(2):127-39.

4. Amin HE. Clinical and antibacterial effectiveness of three different sealant materials. J Dent Hyg. 2008 Fall;82(5):45.

5. Dukic W, Dukic OL, Milardovic S, Vindakijevic Z. Clinical comparison of flowable composite to other fissure sealing materials--a 12 months study. Coll Antropol. 2007 Dec;31(4):1019-24.

6. Kubo S, Yokota H, Yokota H, Hayashi Y. Three-year clinical evaluation of a flowable and a hybrid resin composite in non-carious cervical lesions. J Dent. 2010 Mar;38(3):191-200.

7. Ryou DB, Park HS, Kim KH, Kwon TY. Use of flowable composites for orthodontic bracket bonding. Angle Orthod. 2008 Nov;78(6):1105-9.

8. Baroudi K, Rodrigues JC. Flowable Resin Composites: A Systematic Review and Clinical Considerations. Angle Orthod. 2008 Nov;78(6):1105-9.

9. Baroudi K, Silikas N, Watts DC. Time-dependent visco-elastic creep and recovery of flowable composites. Eur J Oral Sci. 2007 Dec;115(6):517-21.

10. Chuang SF, Liu JK, Chao CC, Liao FP, Chen YH. Effects of flowable composite lining and operator experience on microleakage and internal voids in class II composite restorations. J Prosthet Dent. 2001 Feb;85(2):177-83.

11. Sabbagh J, Ryelandt L, Bacherius L, Biebuyck JJ, Vreven J, Lambrechts $P$, et al. Characterization of the inorganic fraction of resin composites. J Oral Rehabil. 2004 Nov;31(11):1090-101.

12. Kucukyilmaz E, Savas S. Evaluation of Different Fissure Sealant Materials and Flowable Composites Used as Pit-and-fissure Sealants: A 24-Month Clinical Trial. Pediatr Dent. 2015 SepOct;37(5):468-73.

13. Vichi A, Margvelashvili M, Goracci C, Papacchini F, Ferrari M. Bonding and sealing ability of a new self-adhering flowable composite resin in class I restorations. Pediatr Dent. 2015 SepOct;37(5):468-73.

14. Schulz KF, Altman DG, Moher D. CONSORT 2010 statement: Up dated guidelines for reporting parallel group randomised trials. J Pharmacol Pharmacother. 2010 Jul;1(2):100-7.

15. Loguercio AD, de Paula EA, Hass V, Luque-Martinez I, Reis A, Perdigao J. A new universal simplified adhesive: 36-Month randomized double-blind clinical trial. J Dent. 2015 Sep;43(9):10831092.

16. Loguercio AD, Manica D, Ferneda F, Zander-Grande C, Amaral R, Stanislawczuk $R$, et al. A randomized clinical evaluation of a oneand two-step self-etch adhesive over 24 months. Oper Dent. 2010 May-Jun;35(3):265-72

17. Perdigao J, Kose C, Mena-Serrano AP, De Paula EA, Tay LY, Reis A, et al. A new universal simplified adhesive: 18-month clinical evaluation. Oper Dent. 2014 Mar-Apr;39(2):113-27.
18. MeSH Browser [database on the Internet]. J. Sabbagh and P. Souhaid, Vertise Flow Composite; A Breakthrough in Adhesive Dentistry, 2011, http://www.oralhealthjournal.com.

19. Vichi, CG; Ferrari, $M$ - editors. Clinical study of the self-adhering flowable composite resin Vertise Flow in Class I restorations: sixmonth follow-up. International Dentistry SA, vol. 12, no. 1, 2010. pp. 14-23.

20. Kitasako Y, Sadr A, Burrow MF, Tagami J. Thirty-six month clinical evaluation of a highly filled flowable composite for direct posterior restorations. Aust Dent J. 2016 Sep;61(3):366-73.

21. Wei YJ, Silikas N, Zhang ZT, Watts DC. Hygroscopic dimensional changes of self-adhering and new resin-matrix composites during water sorption/desorption cycles. Dent Mater. 2011 Mar;27(3):259-66.

22. Loguercio AD, Bittencourt DD, Baratieri LN, Reis A. A 36-month evaluation of self-etch and etch-and-rinse adhesives in noncarious cervical lesions. J Am Dent Assoc. 2007 Apr;138(4):507-14; quiz 535-7.

23. Moosavi H, Kimyai S, Forghani M, Khodadadi R. The clinical effectiveness of various adhesive systems: an 18-month evaluation. Oper Dent. 2013 Mar-Apr;38(2):134-41.

24. Perdigao J, Dutra-Correa M, Saraceni CH, Ciaramicoli MT, Kiyan VH, Queiroz CS. Randomized clinical trial of four adhesion strategies: 18-month results. Oper Dent. 2012 Jan-Feb;37(1):3-11.

25. Labella R, Lambrechts P, Van Meerbeek B, Vanherle G. Polymerization shrinkage and elasticity of flowable composites and filled adhesives. Dent Mater 1999;15(2):128-37.

26. Lawson NC, Radhakrishnan R, Givan DA, Ramp LC, Burgess JO. Two-year Randomized, Controlled Clinical Trial of a Flowable and Conventional Composite in Class I Restorations. Oper Dent. 2015 Nov-Dec;40(6):594-602.

27. Rocha Gomes Torres C, Rego HM, Perote LC, Santos LF, Kamozaki $\mathrm{MB}$, Gutierrez NC, et al. A split-mouth randomized clinical trial of conventional and heavy flowable composites in class II restorations. J Dent. 2014 Jul;42(7):793-9.

28. Park JW, Ferracane JL. Water aging reverses residual stresses in hydrophilic dental composites. J Dent Res. 2014 Feb;93(2):195200.

29. Peumans M, Kanumilli P, De Munck J, Van Landuyt K, Lambrechts $P$, Van Meerbeek B. Clinical effectiveness of contemporary adhesives: a systematic review of current clinical trials. Dent Mater. 2005 Sep;21(9):864-81

30. Moura SK, Pelizzaro A, Dal Bianco K, de Goes MF, Loguercio AD, Reis $A$, et al. Does the acidity of self-etching primers affect bond strength and surface morphology of enamel? J Adhes Dent. 2006 Apr;8(2):75-83.

31. Sabbagh J, Dagher S, El Osta N, Souhaid P. Randomized Clinical Trial of a Self-Adhering Flowable Composite for Class I Restorations: 2-Year Results. Int J Dent. 2017;2017:5041529.

32. Corona SA, Borsatto MC, Garcia L, Ramos RP, Palma-Dibb RG. Randomized, controlled trial comparing the retention of a flowable restorative system with a conventional resin sealant: oneyear follow up. Int J Paediatr Dent. 2005 Jan;15(1):44-50.

33. Eliades A, Birpou E, Eliades T, Eliades G. Self-adhesive restoratives as pit and fissure sealants: a comparative laboratory study. Dent Mater. 2013 Jul;29(7):752-62. 